\title{
Metamorphism of the Müllerneset Formation, St. Jonsfjorden, Svalbard
}

\author{
JAY JAMES AGUE and ALAN PAUL MORRIS
}

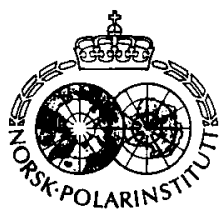

Ague, J. J. \& Morris, A. P. 1985: Metamorphism of the Müllerneset Formation, St. Jonsfjorden, Svalbard. Polar Research 3 n.s., 93-106.

The metamorphism of upper greenschist facies metasediments exposed in the extreme southwestern portion of St. Jonsjorden, Svalbard, is described. The rocks form part of the Müllerneset Formation of the late Precambrian age Kongsvegen Group and constitute a portion of the central-western Spitsbergen Caledonides. Four deformations $\left(D_{1}-D_{4}\right)$ and two metamorphic episodes $\left(M_{1}\right.$ and $\left.M_{2}\right)$ have affected the rocks of the Müllerneset area. $M_{1}$ was a prograde event which was initiated prior to the onset of the $D_{1}$ and continued through this deformation. Pre- $D_{1}$ metamorphism reached biotite grade whereas garnet grade was attained syn- $D_{1} . M_{2}$ was a lower-middle greenschist facies metamorphism associated with $D_{2}$. The results of quantitative geothermometry in the pelitic rocks show that peak $\mathrm{M}_{1}$ metamorphic temperatures decrease southwards across the field area from about $540^{\circ} \mathrm{C}$ to $510^{\circ} \mathrm{C}$. Geobarometry and estimates of depth of burial indicate that $\mathrm{M}_{1}$ pressures were in the range of 5-7 kb. The data are consistent with geothermal gradients in the range of $21 \pm 4^{\circ} \mathrm{C} / \mathrm{km}$ to $24 \pm 5^{\circ} \mathrm{C} / \mathrm{km} . \mathrm{M}_{2}$ metamorphic conditions are not precisely determinable but temperatures and pressures were probably less than those attained during $\mathbf{M}_{1}$. It is suggested that the rocks of central-western Spitsbergen were originally deposited in an aulacogen before the initiation of Caledonian diastrophism.

Jay James Ague, Department of Geology, Deparment of Geology and Geophysics, University of California, Berkeley, California 94720, USA; Alan Paul Morris, Division of Earth and Physical Sciences, University of Texas at San Antonio, San Antonio, Texas 78285, USA; January 1984 (revised August 1984).

\section{Introduction}

The pre-Carboniferous rocks of Oscar II land and Prins Karls Forland, Svalbard, constitute the Western and Forland Complexes, respectively, and are believed to be northern extensions of the Appalachian/Caledonian orogen (Harland et al. 1979) (Fig. 1). A number of workers (e.g. Holtedahl 1911, 1933; Tyrell 1924; Orvin 1934; Weiss 1953; Dineley 1958; Atkinson 1960; Cutbill \& Challinor 1965; Winsnes 1965; Horsfield 1969; Scrutton et al. 1976; Manby 1978a; Harland \& Wright 1979; Harland et al. 1979; Hjelle et al. 1979; Ohta 1979) have made important contributions to our understanding of the general geology and tectonic evolution of the region. In this paper, we describe the metamorphism of upper greenschist facies (garnet zone) meta-sediments from Oscar II Land and discuss the tectonic implications of the metamorphic episodes recorded in the rocks. The examined lithologies comprise the Müllerneset Formation of the Late Precambrian age Kongsvegen Group (stratigraphic terminology of Hariand et al. 1979).

\section{Geologic setting}

The pre-Carboniferous rocks of central western Spitsbergen may be divided into two packages. The lower package, of late Precambrian to Cambrian age, is dominantly miogeoclinal in nature and consists of glaciogenic mixtites, platform carbonates, pelites, psammites, and lesser amounts of mafic to intermediate igneous material (Harland et al. 1979). The upper package, which is exposed within Oscar II Land, represents a more active tectonic environment and comprises massive conglomerates, calcareous psammites, pelites and carbonates. This sequence is interpreted to be a syn-orogenic molasse deposit (Morris et al. 1983) and is of Siluro-Ordovician age (Scrutton et al. 1976). The Forland and Western Complexes have been affected by four deformational events $\left(D_{1}-D_{4}\right)$, all of which are represented within the Müllerneset Formation. A major progade metamorphism $\left(\mathbf{M}_{1}\right)$ took place prior to and synchronous with $D_{1}$ and a later retrograde event $\left(M_{2}\right)$ was broadly synchronous with $D_{2}$. The lower package records $D_{1}$ through $D_{4}$ and both metamorphic 


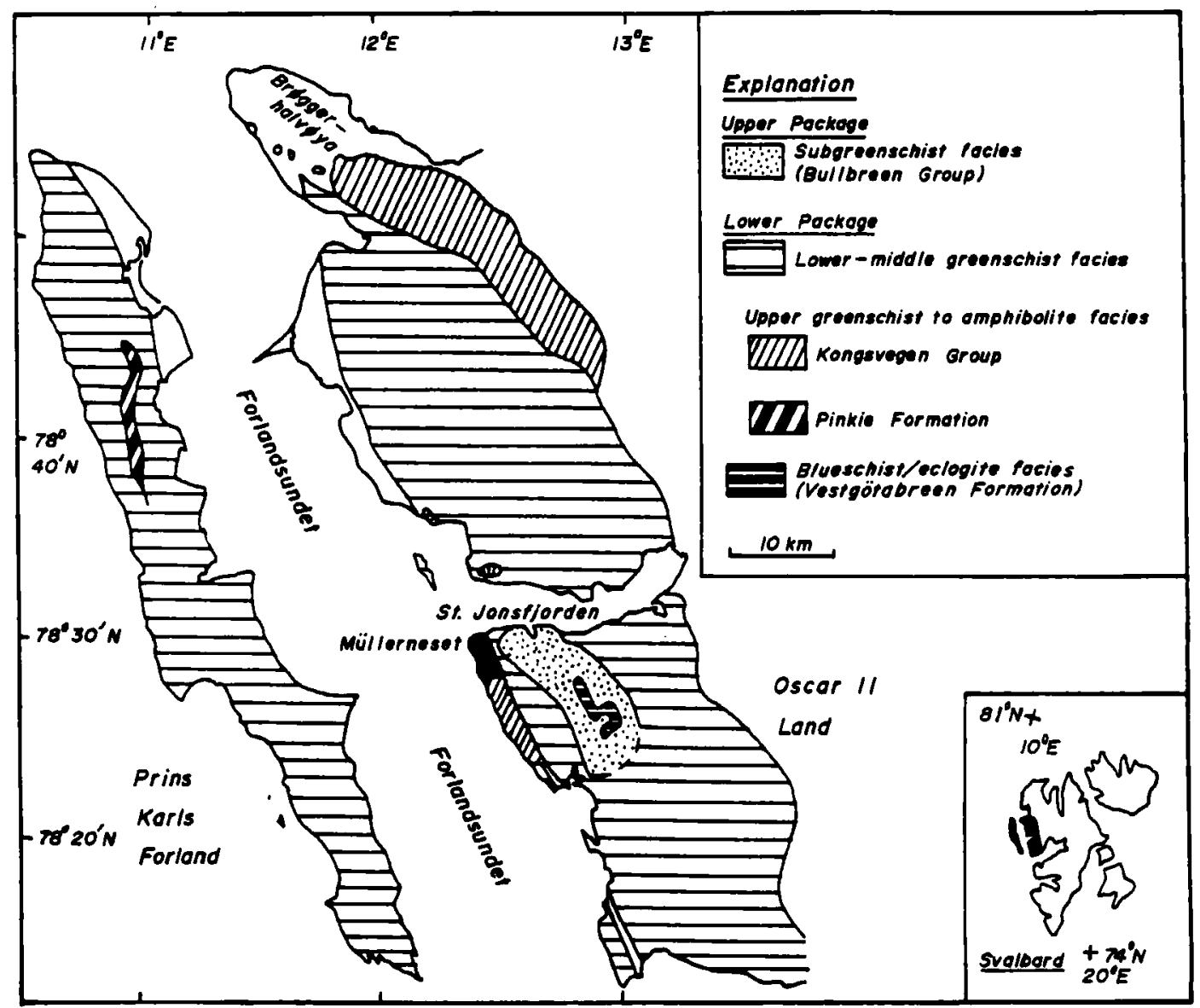

Fig. 1. Map showing the distribution of metamorphic facies within central-western Spitsbergen. Data sources: Harland et al. 1979; Hjelle et al. 1979; Manby 1983a.

events whereas the upper contains evidence of $D_{2}, D_{3}$, and $D_{4}$ and shows only incipient metamorphism (Fig. 1). Lithologies of the Müllerneset Formation were affected by all of the deformational and metamorphic episodes and therefore constitute part of the lower package. Although the ages of diastrophism are not yet precisely known, it is thought that $D_{1}$ and $M_{1}$ are Caledonian sensu lato in age whereas the later episodes are Tertiary (Challinor 1967; Morris 1979). However, recent work indicates that $D_{2}$ and $M_{2}$ may in fact be manifestations of late-stage Caledonian tectonism (Hjelle et al. 1979; Morris et al. 1983).

Garnet-biotite schists of the Müllerneset Formation outcrop in a narrow $(1 \times 13 \mathrm{~km})$ thrust slice along Forlandsundet (Fig. 1). This work deals with the metamorphism of the northern portion of the sequence, exposed on the south shore of St. Jonsfjorden, in the vicinity of Müllerneset (Fig. 2). To facilitate study, the field area has been divided into three subareas. Pelites, semi-pelites, and psammites are the predominant lithologies, although lesser amounts of intercalated carbonate material are also present. The total thickness of the Müllerneset Formation exposed within the field area is approximately $850 \mathrm{~m}$. The rocks have been subjected to four deformational events, the effects of which are summarized in Table $1 . M_{1}$ metamorphism produced mineral assemblages characteristic of the garnet zone in pelitic lithologies, although there is a decrease in metamorphic grade southwards from subarea 1 to subarea 3. The Müllerneset is in thrust contact with a group of unmetamorphosed Permo-Carboniferous limestones and dolomites (Cutbill \& Challinor 1967) which out- 
crop in the easternmost portion of the field area. Farther east, within St. Jonsfjorden, lower package meta-sedimentary and meta-igneous rocks, metamorphosed to chlorite grade, and subgreenschist facies upper package lithologies are exposed. Five kilometres south of St.
Jonsfjorden and ten kilometres inland of Forlandsundet, blueschist/eclogite facies rocks and serpentinites of the Vestgötabreen Formation outcrop (Horsfield 1969; Manby 1978b; Ohta 1979). Stratigraphic schemes for the St. Jonsfjorden region are presented in Krasil'scikov \&

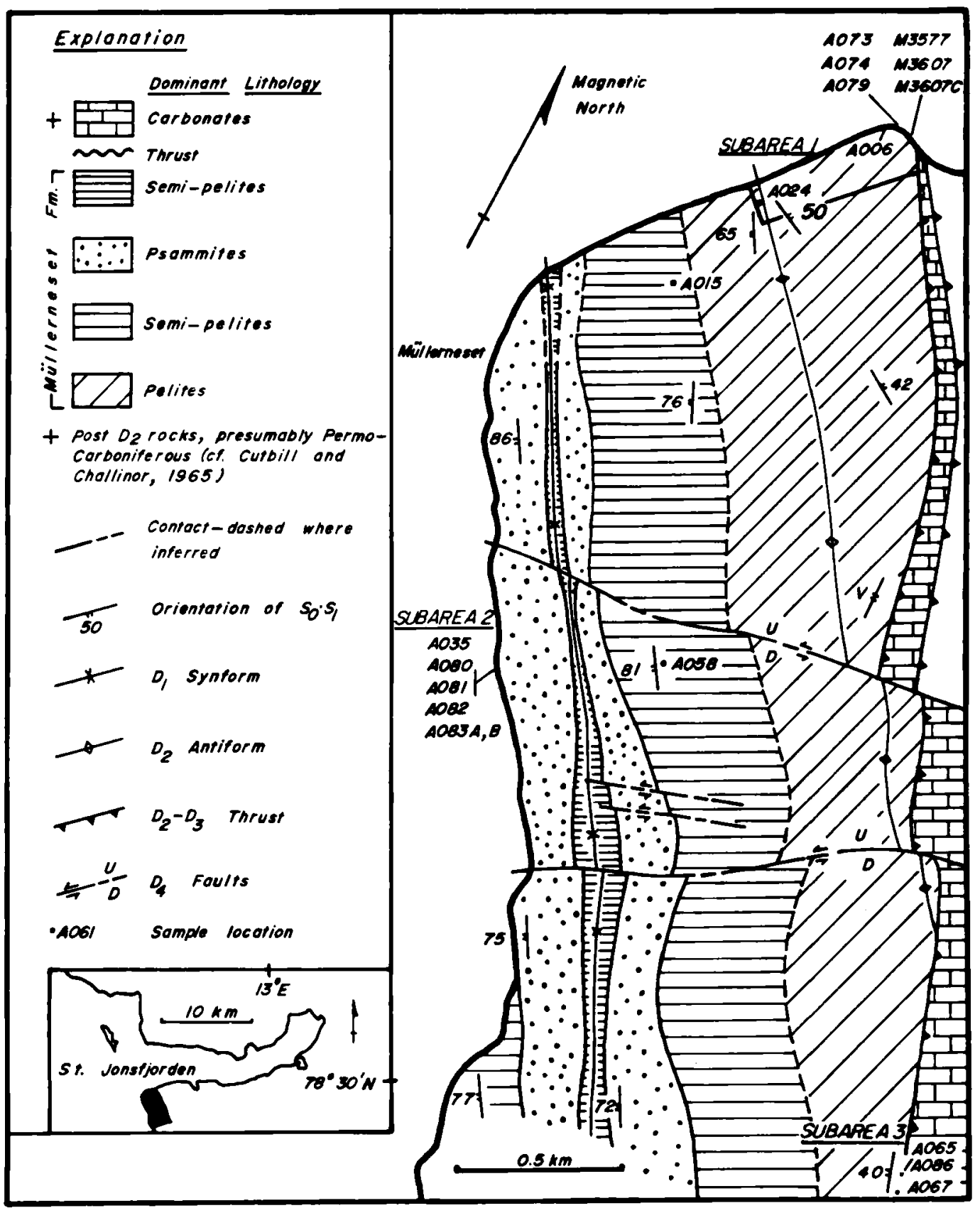

Fig. 2. Generalized geologic map of the field area. 
Table 1. Deformational history of the Müllerneset Formation.

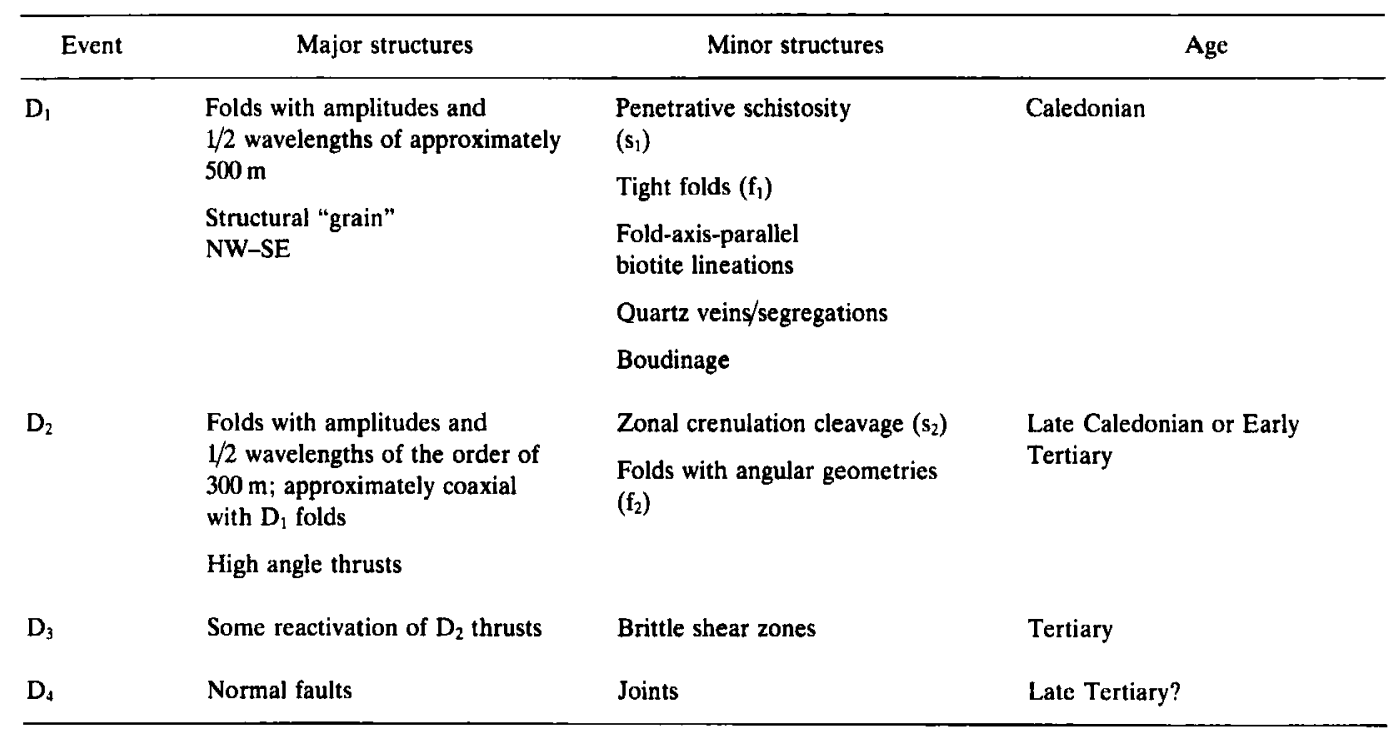

Kovaleva (1979), Harland et al. (1979), Hjelle et al. (1979), and Waddams (1983).

\section{Previous work}

Relatively little attention has been focused on the Müllerneset Formation in recent years. The structural characteristics of the rocks have been investigated by Weiss (1953), Hjelle et al. (1979), and Ague \& Morris (1983). The metamorphism of the Müllerneset lithologies has not been discussed in detail previously although Horsfield (1969), Manby (1978b), Harland et al. (1979), Hjelle et al. (1979), and Ohta (1979) have commented upon the mineral assemblages present in the rocks. Horsfield (1969), and Manby (1978b) give estimates of Kongsvegen Group metamorphic conditions which range from $\mathrm{T}=300^{\circ} \mathrm{C}$ maximum (Horsfield) to $\mathrm{T}-550^{\circ} \mathrm{C}$ maximum and $\mathrm{P}=$ approximately $8 \mathrm{~kb}$ (Manby).

\section{Metamorphic textures}

Textural relationships between metamorphic mineral phases provide a detailed record of the timing of metamorphism and deformation within the Müllerneset Formation. Unless otherwise noted, the discussion of metamorphic textures which follows is limited to pelitic rocks because they contain the most complete record of periods of crystallization.

\section{$M_{1}$ textures}

There are three phases of mica growth preserved within the rocks. The first two are pre-tectonic whereas the third crystallized synchronous with $D_{1}$ (Fig. 3A). The $s_{1}$ schistosity is well developed in the pelitic rocks of the field area and is penetrative at hand specimen scale. Under the microscope, this foliation is seen to post-date two earlier generations of mica growth. The first fabric $\left(s_{0}\right)$ could be a mimetic recrystallization of mica after the original sedimentary bedding or a relict foliation derived from an earlier (pre- $D_{1}$ ) deformation event. However, the lack of any other structures attributable to deformation older than those ascribed to $D_{1}$ (such as refolded folds) argues against the latter interpretation. Overprinting this early foliation is a phase of mica growth marked by randomly oriented books and decussate clots of biotite. Both of these generations of mica are deformed by the $s_{1}$ schistosity which is defined by relatively strain-free plates of muscovite and biotite aligned sub-parallel to one another. The above observations indicate that the 
A.

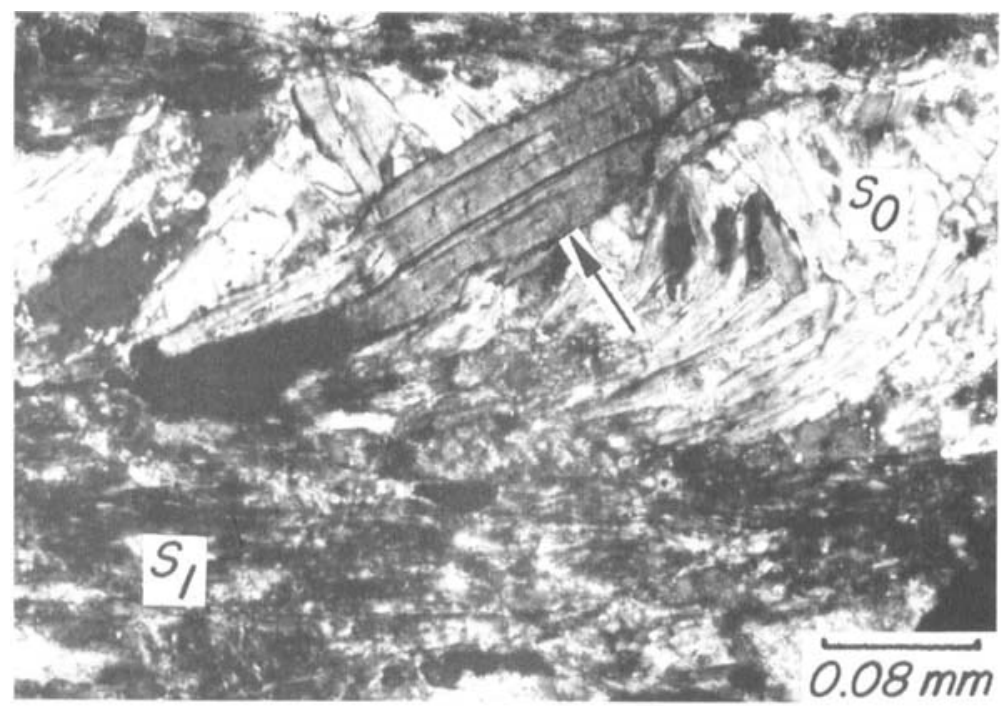

Fig. 3. Metamorphic textures. A. Three generations of mica growth preserved within the pelites. Note that the earliest foliation $\left(s_{0}\right)$ has been overprinted by a later phase of biotite growth (arrow). The $\mathrm{s}_{1}$ schistosity represents the last period of crystallization (sample M3607; NX). B. Syn-tectonic garnet (sample M3607; NX).

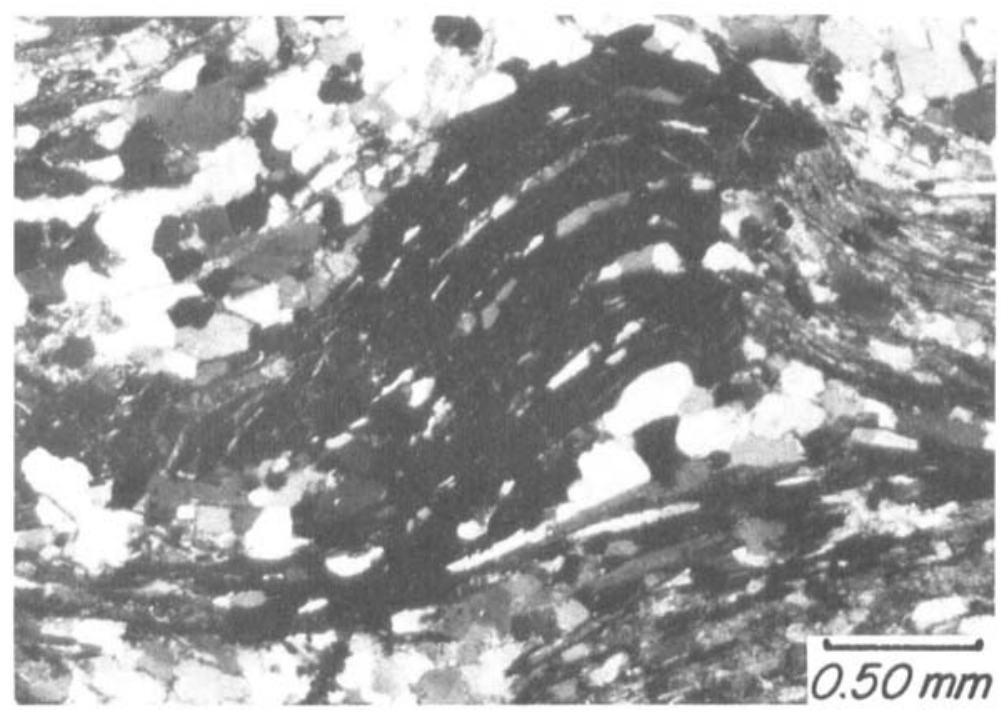

first two episodes of mica crystallization occurred under hydrostatic stress conditions before the onset of deformation while the third phase was syn-tectonic.

The degree and nature of $s_{l}$ development varies throughout the field area. The schists from subareas 1 and 2 are generally well differentiated into micaceous and quartzofeldspathic domains whereas those of subarea 3 are poorly differentiated. The micaceous and quartzofeldspathic layers probably developed through metamorphic differentiation processes, although the compositional heterogeneity of the sedimentary protolith may also have been important in some cases. The variations in compositional layering are mirrored by phyllosilicate grain size changes; individual mica plates are visible to the naked eye in the schists from subareas 1 and $2(0.5-1.5 \mathrm{~mm})$ but are much less obvious (except for occasional clots of biotite visible on $s_{1}$ cleavage surfaces) in the rocks from subarea $3(<0.1-0.5 \mathrm{~mm})$.

In general, garnets within the schists display syn-tectonic crystallization textures (Fig. 3B). For example, most garnets contain sigmoidal quartz inclusion trails which are indicative of syn-tectonic development (Spry 1963; Schonoveld 1978). The 
presence of quartz pressure shadows adjacent to some of the garnets and the wrapping of $s_{1}$ cleavage planes around the porphyroblasts imply that garnet growth may have ended before $D_{1}$ ended.

On the basis of textural evidence, the main metamorphic peak (garnet grade) is interpreted to have occurred synchronously with $D_{1}$, while biotite grade metamorphic conditions were attained prior to $D_{1}$. Pre- to syntectonic metamorphic mineral growth has also been observed in the rocks of Prins Karls Forland (Manby 1978b, 1983a, b; Morris 1979, 1982) and the Vestgötabreen Formation (Manby 1978b) although the latter also contains evidence of post-tectonic crystallization.

\section{$M_{2}$ textures}

Although $D_{2}$ was a relatively 'strong' deformation, structures attributable to this event are irregularly developed throughout the field area. In rocks which have been affected by intense $D_{2}$ deformation (as evidenced by well developed $s_{2}$ cleavage and $f_{2}$ folds) garnet-biotite pairs retrogress to chlorite \pm epidote and, occasionally, garnets are completely chloritized. However, biotite by itself retrogresses only rarely. $D_{2}$ deformation also produced fractures in many of the garnets, and shear zones (e.g. Gregg 1978) in some of them. In rocks which have not suffered extensive $D_{2}$ deformation, retrograde textures are rare. These observations suggest that $\mathbf{M}_{2}$ retrogression was more or less synchronous with $D_{2}$. The introduction of fluids necessary for $\mathbf{M}_{2}$ retrograde metamorphism may have occurred along the many small quartz and calcite filled fractures $(0.2-0.4 \mathrm{~mm}$ wide) within the schists. That these fractures are of $D_{2}$ age is evidenced by their cross-cutting relationship with $D_{1}$ structures, and their approximate parallelism with $D_{2}$ fold axial surfaces. Indeed, the introduction of fluids may have triggered $D_{2}$ deformation by weakening the rocks, as suggested by many workers (e.g. Fyfe et al. 1978). Whether or not $M_{2}$ actually began before $D_{2}$ is difficult to determine however.

Post- $\mathbf{M}_{1}$ retrograde assemblages have been observed in specimens from Prins Karls Forland (Morris 1982; Manby 1983b), and within the Vestgötabreen Formation (Manby 1978b; Ohta 1979) but the retrogression is generally interpreted to have occurred synchronously with $D_{1}$ in these rocks.

\section{Petrology}

\section{Analytical techniques}

Whole-rock $x$-ray fluorescence analyses were performed by X-ray Assay Laboratories, Don Mills, Ontario. Electron microprobe analysis was carried out by one of us (JJA), under the direction of $\mathbf{R}$. L. Barnett, on an automated Materials Analysis Company instrument at the University of Western Ontario. Between one and four analyses were performed on unzoned minerals and within subdomains of zoned phases. The results of more than one analysis of an individual grain or subdomain were averaged. Representative mineral and whole-rock analyses are presented in Appendices 1 and 2.

\section{Mineral assemblages}

The mineral assemblages present within rocks of each of the compositional groups are summarized below:

Pelites: biotite + muscovite + quartz \pm almandine \pm feldspar \pm chlorite \pm epidote \pm calcite \pm opaques \pm graphite

Semi-pelites: biotite + muscovite + quartz \pm feldspar \pm chlorite \pm calcite \pm ankerite \pm opaques

Psammites: muscovite + feldspar + quartz \pm biotite \pm opaques \pm graphite

Carbonates: biotite + muscovite + feldspar + quartz + calcite \pm almandine \pm dolomite \pm chlorite \pm epidote \pm opaques

Staurolite and the $\mathrm{Al}_{2} \mathrm{SiO}_{5}$ polymorphs are absent from all of the rocks studied.

\section{Description of pelitic phases}

The following are brief descriptions of the physical and chemical characteristics of the mineral phases present within the pelites. The discussion is limited to pelites because these rocks contain the most useful petrologic information.

Garnet. - Garnetiferous pelites which have not been severely retrograded or weathered outcrop at three locations (subareas 1-3) within the field area (Fig. 2). Garnets occur as euhedral to anhedral porphyroblasts which contain inclusions of quartz and, more rarely, feldspar, chlorite, 
epidote, calcite, and opaques. Garnet size decreases southwards, with average garnet diameters of $5 \mathrm{~mm}, 3 \mathrm{~mm}$, and $1.5 \mathrm{~mm}$ for subareas 1,2 , and 3 , respectively.

Compositionally, the garnets are almandine solid solutions which contain varying amounts of $\mathrm{Mn}, \mathrm{Ca}$, and $\mathrm{Mg}$. In particular, the spessartine component is the most variable with $\mathrm{X}_{\mathrm{sp}}$ (garnet rim) ranging from 0.05 to about 0.20 . The rims of subarea 2 and 3 garnets are more Mn-rich than those of subarea 1 . The unusually manganiferous garnets of subarea 2 occur within graphitic schists which contain appreciable amounts of sulfide material (pyrite and pyrrhotite). It is probable that reactions such as:

pyrite + Fe-silicates + graphite $=$ pyrrhotite + Fe-poorer silicates $+\mathrm{CO}_{2}$

(Carpenter 1974)

occurred within these lithologies since Mn may serve to stabilize garnet in lieu of $\mathrm{Fe}$ in an Fedepleted system (Mohr \& Newton 1983). Garnets from subareas 1 and 2 are normally zoned (e.g. Brown 1969) whereas those from subarea 3 are unzoned. In general, the garnets from subarea 1 schists display the best developed zoning profiles.

Other phases. - None of the other analyzed phases show any consistent, detectable compositional zoning. Plagioclase is dominantly oligoclase $\left(A n_{12-22}\right)$ although a few grains of nearly pure albite were noted in several samples. Plagioclase (and quartz) grain sizes are in the $0.1-0.3 \mathrm{~mm}$ range. Biotites are universally Fe-rich and muscovites generally contain an appreciable amount of phengite component. No chemical differences were noted between pre- and syn-deformational biotite and muscovite within a single thin section. Mica grain sizes range from $0.5-1.5 \mathrm{~mm}$ (subarea 1) to $<0.1-0.5 \mathrm{~mm}$ (subarea 3). Chlorite occurs in samples affected by strong $\mathrm{D}_{2}$ deformation as a retrograde mineral, replacing prograde garnet and, more rarely, biotite. In addition, two rocks from subareas 1 and 2 (M3577, A035) contain chlorite which does not display replacive textures and is thus inferred to be a prograde mineral. Both prograde and retrograde chlorites fall within the ripidolite field of Hey (1954) although retrograde chlorite tends to be more Fe-rich than prograde chlorite. It is probable that the breakdown of Fe-rich garnet produced chlorite with a relatively low $\mathrm{Mg} /(\mathrm{Mg}+\mathrm{Fe}$ ) ratio (e.g. Albee 1965).
Tiny $(0.01-0.05 \mathrm{~mm})$ grains of epidote are sometimes found associated with patches of retrograde chlorite which replace garnet. This mode of occurrence strongly suggests that the epidote is also a retrograde mineral. Calcite is quite rare within the pelites. Its most common occurrence is in late-stage quartz-calcite veins $(0.2-0.4 \mathrm{~mm}$ wide) which transect features produced during $M_{1}$ and $D_{1}$. Ilmenite (generally altered to leucoxene in subarea 3 samples), magnetite, pyrite, and pyrrhotite are the primary metallic phases present within the rocks. Some hematite also occurs and this is interpreted to have developed through supergene oxidation of pre-existing magnetite. Graphite is found as finely disseminated dust or irregularly shaped aggregates up to about $0.2 \mathrm{~mm}$ across. The rocks of subarea 2 are particularly rich in graphite and sulfide material. Trace amounts of tourmaline, apatite, and zircon occur in virtually all the specimens studied.

\section{Equilibrium criteria}

Evidence for chemical equilibrium in metamorphic rocks is usually equivocal and, in addition, there is little agreement between workers as to what constitutes as 'equilibrium assemblage'. The following points suggest, but do not necessarily prove, that equilibrium was attained in the rocks of each subarea. Contacts between phases are generally quite sharp and do not show extensive alteration (except in rocks which have been strongly overprinted by $\mathrm{M}_{2}$ ). In addition, a given mineral phase does not change appreciably in composition within a single thin section.

AFM projections (Thompson 1957) of garnet (rim)-biotite pairs for each of the three subareas show a systematic displacement of tie-lines which strongly suggests that samples from individual subareas crystallized in equilibrium with each other (Fig. 4). However, the composite plot of all tie-lines (Fig. 4) displays a number of crossing tie-line relationships which indicates that physical conditions and/or values of chemical potentials of projected components were variable throughout the field area during $\mathbf{M}_{1}$ metamorphism. The diagrams also show that chlorites displaying replacive (retrograde) textures are more $\mathrm{Fe}$-rich than the non-replacive variety.

\section{Garnet producing reactions}

Many reactions have been described or proposed 


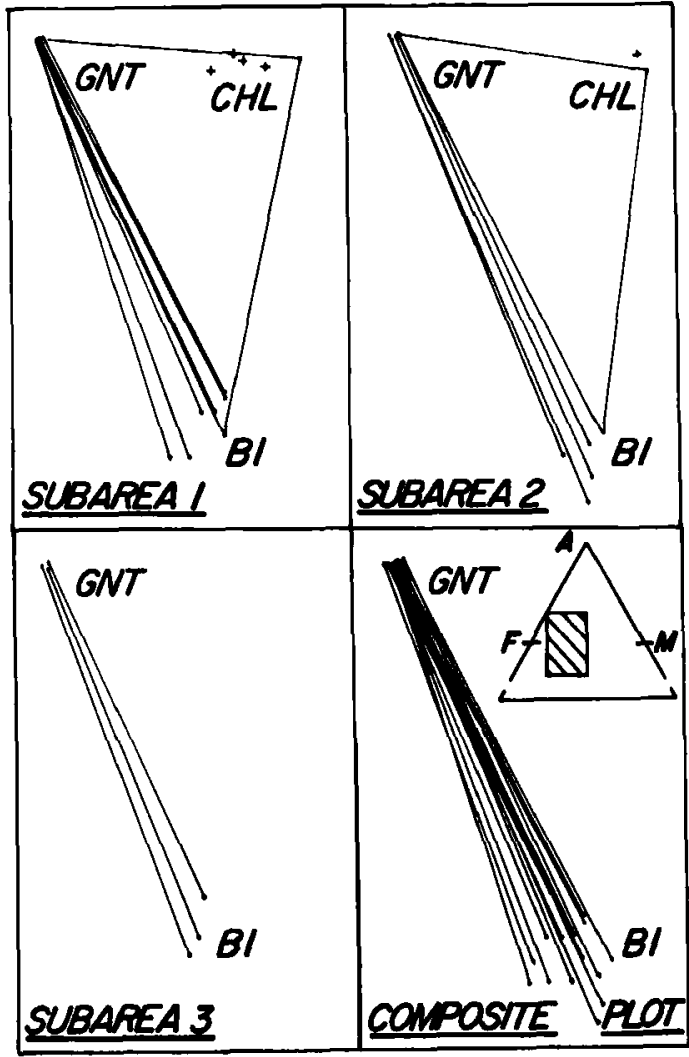

Fig. 4. AFM projections (Thompson 1957) of coexisting garnet, biotite, and chlorite. Crosses indicate retrograde chlorite (no tie-lines). Projections for rocks of each subarea are shown along with a composite plot of all tie-lines between coexisting garnet-biotite pairs. Note the crossing tie-line relationships on the composite plot.

in the literature to account for the first appearance of almandine-rich garnet in pelitic rocks:

$$
\text { Chloritoid + Biotite + Quartz }
$$$$
=\text { Garnet }+\mathrm{H}_{2} \mathrm{O}
$$

(Thompson \& Norton 1968)

Chlorite + Biotite + Quartz

$=$ Garnet + Biotite $_{2}+\mathrm{H}_{2} \mathrm{O}$

(Chakraborty \& Sen 1967)

Chlorite + Muscovite + Quartz

$=$ Garnet + Biotite $+\mathrm{H}_{2} \mathrm{O}$

(Thompson \& Norton 1968)

Chlorite + Muscovite + Epidote

$=$ Garnet + Biotite $+\mathrm{H}_{2} \mathrm{O}$

(Brown 1969)

It is difficult to determine which reaction(s) operated in the pelites because the rocks lie on the high side of the almandine isograd and, there-

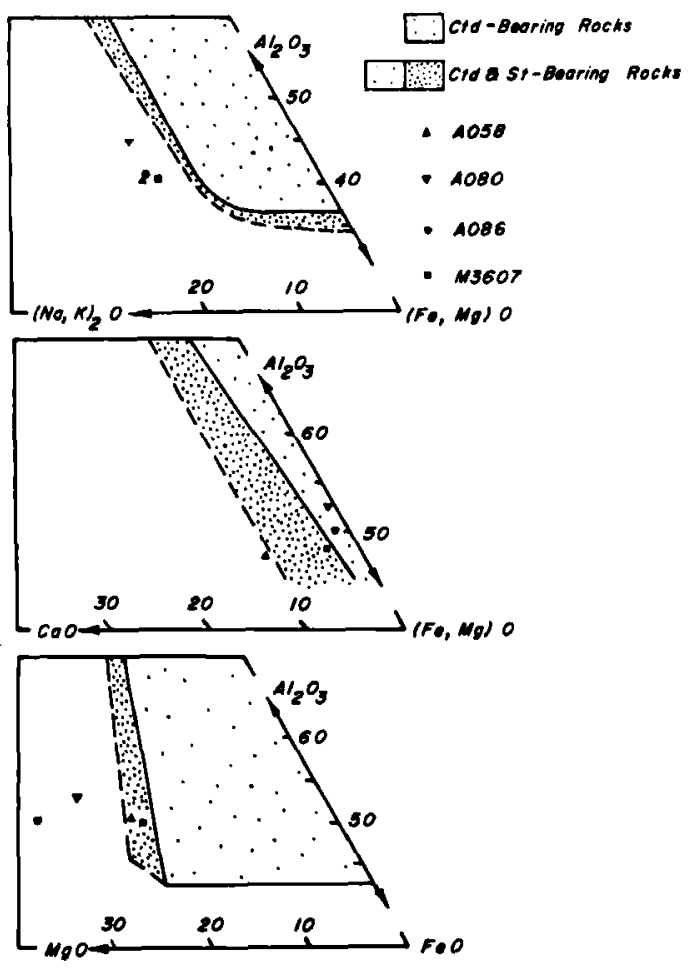

Fig. 5. Whole-rock compositions which favor the formation of staurolite and chloritoid (after Hoschek 1967) and whole-rock compositions of four 'representative' schists.

fore, assemblages transitional between the biotite and garnet zones are not present within the field area. However, some comments can be made. Reaction (1) is unlikely because whole-rock compositions of four representative schists are not suitable for chloritoid formation (Fig. 5). In addition, no evidence of chloritoid has been found in any of the rocks. Since prograde chlorite is extremely rare within the pelites, it was probably consumed in garnet generating reactions such as (2), (3), and (4). Reaction (2) is possible, although it should be noted that biotite compositions are uniform within a single thin section. It is probable that reactions similar to (3) and (4) produced most of the garnet present in the rocks. Reaction (4) is particularly attractive since it provides a mechanism for the entry of $\mathrm{Ca}$ (from epidote) into garnet. Epidote (and carbonate phases) may also have been utilized in reactions which produce calcic plagioclase (e.g. Crawford 1966), athough available evidence is inconclusive.

The pelitic mineral assemblages indicate that the rocks were metamorphosed at temperatures 
of about $500^{\circ} \mathrm{C}$ or greater and pressures of at least 3-4 kb at the peak of $\mathrm{M}_{1}$ metamorphism (Winkler 1979; Turner 1981).

\section{Thermobarometry}

Since the assemblages present in the rocks only generally fix the P-T regime of metamorphism, thermobarometry was undertaken in the pelites to determine metamorphic conditions more accurately. A number of garnet-biotite thermometers are presently available (e.g. Thompson 1976; Goldman \& Albee 1977; Perchuk 1977; Ferry \& Spear 1978). The Ferry \& Spear (1978) calibration is used here because it corrects for pressure effects, although it should be noted that the garnet-biotite $\mathrm{Fe}-\mathrm{Mg}$ exchange reaction is highly insensitive to pressure. Temperature calculations were carried out at a reference pressure of $6 \mathbf{k b}$. Non-ideal solution behavior in garnet was accounted for utilizing the correction proposed by Hodges \& Spear (1982). Pressures were calculated using the plagioclase-biotite-garnet-muscovite thermobarometer of Ghent \& Stout (1981). Only garnet rim compositions were employed for the purposes of thermometry and barometry (cf. Pigage \& Greenwood 1982).
Computed pressures and temperatures are presented in Table 2. Uncorrected temperatures are similar for subareas 1 and $2\left(490^{\circ} \mathrm{C}\right)$ whereas subarea 3 temperatures are about $20^{\circ} \mathrm{C}$ lower. Corrected temperatures are $30-50^{\circ} \mathrm{C}$ higher and show a decrease in metamorphic grade southwards from subarea 1 to subarea 3 . These results illustrate the importance of correcting for nonideal solution behavior in garnet when metamorphic temperatures are calculated.

The computed temperature variations correspond well with qualitative grade indicators. As noted above, both the degree of metamorphic differentiation and phyllosilicate and garnet grain sizes increase northwards. In addition, the most Fe-rich garnets occur within the schists of subarea 1 which strongly suggests that metamorphic temperatures were higher there than elsewhere within the field area (Tracy 1982). Furthermore, the AFM projections indicate that the rocks of an individual subarea did not crystallize in equilibrium with rocks from other subareas. At present it is unclear whether the calculated temperature variations represent a gradual north-south grade change as a result of differential uplift along the east-west trending $D_{4}$ faults which cut through the central portion of the field area (Fig. 2), or

Table 2. Calculated pressures and temperatures of metamorphism.

\begin{tabular}{|c|c|c|c|c|}
\hline & Sample & $\begin{array}{c}\mathrm{T}^{\circ} \mathrm{C} \\
\text { (uncorrected) }\end{array}$ & $\begin{array}{c}\mathrm{T}^{\circ} \mathrm{C} \\
\text { (corrected) }\end{array}$ & P bars \\
\hline \multirow[t]{8}{*}{ Subarea 1} & A0006 & 503 & 556 & 6,338 \\
\hline & A024 & 517 & 548 & \\
\hline & A073 & 499 & 548 & \\
\hline & A074 & 455 & 510 & \\
\hline & A079 & 496 & 532 & \\
\hline & M3577 & 460 & 517 & 6,922 \\
\hline & M3607 & 472 & 539 & \\
\hline & Mean $(\sigma)$ & $486(22)$ & $536(16)$ & $6,630(292)$ \\
\hline \multirow[t]{6}{*}{ Subarea 2} & A035 & 492 & 526 & 5,570 \\
\hline & A081 & 460 & 499 & 5,620 \\
\hline & A082 & 503 & 548 & \\
\hline & A083A & 492 & 523 & 5,827 \\
\hline & A083B & 503 & 538 & \\
\hline & Mean $(\sigma)$ & 490 (16) & $527(17)$ & $5,670(111)$ \\
\hline \multirow[t]{4}{*}{ Subarea 3} & A065 & 475 & 507 & \\
\hline & A067 & 484 & 523 & \\
\hline & A086 & 460 & 499 & \\
\hline & Mean $(\sigma)$ & $473(10)$ & 509 (11) & \\
\hline
\end{tabular}




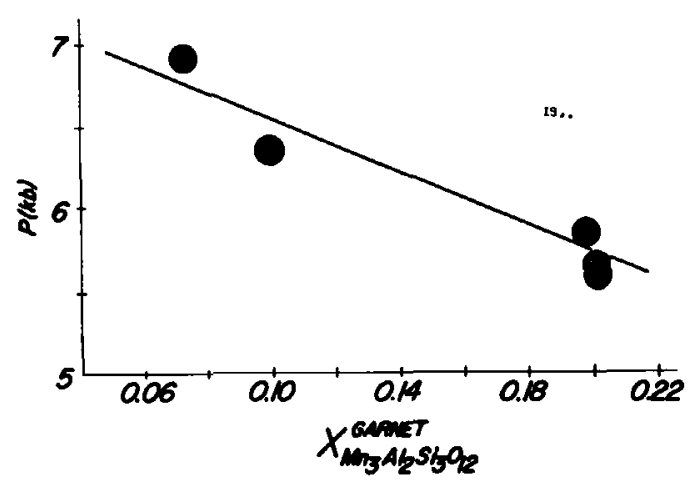

Fig. 6. Plot showing the dependence of computed pressures upon $\mathrm{Mn}$ content of garnet.

a southerly decrease in temperature obtaining at the time of metamorphism.

Metamorphic pressures are more difficult to determine. Since computed temperatures span a range of about $30^{\circ} \mathrm{C}$, it is reasonable to infer that $M_{1}$ pressures did not vary by more than about $0.5 \mathrm{~kb}$ (assuming geothermal gradients of the order of $20-30^{\circ} \mathrm{C} / \mathrm{km}$ ). It is probable that $P_{\text {fluid }}$ approached $\mathrm{P}_{\text {solid }}$ during metamorphism owing to the common occurrence of syn-metamorphic quartz-mica pods throughout the field area (e.g. Albee 1965). Application of the Ghent \& Stout (1982) thermobarometer to five pelites containing coexisting plagioclase-biotite, garnet, and muscovite gives pressure estimates which range from 6.9 to $5.6 \mathrm{~kb}$ for the rocks of subareas 1 and 2 . This thermobarometer was unsuitable for the rocks of subarea 3 because these lithologies did not contain plagioclase coexisting with garnet. Figure 6 shows that there is a strong negative correlation of calculated pressure with Mn content of garnet. Thus the computed pressures may reflect real differences in $\mathbf{M}_{1}$ metamorphic conditions and/or the amount of Mn contained within garnet.

Harland et al. (1979) have estimated tectonostratigraphic thicknesses of slightly over $20 \mathrm{~km}$ obtained in central-western Spitsbergen during Caledonian orogenesis. It is reasonable to assume that the Müllerneset Formation was part of the lower-most portion of the rock package owing to its advanced state of metamorphism when compared with most of the other rocks of the orogen (Harland et al. 1979; Hjelle et al. 1979; Waddams 1983). $20+\mathrm{km}$ of rock material gives overburden pressures which approach $6 \mathrm{~kb}$ (crustal density
$=2.65 \mathrm{~g} / \mathrm{cm}^{3} ;$ Ramberg 1967). Thus, on the basis of the above evidence, we estimate peak $M_{1}$ metamorphic pressures to have been in the range of $5-7 \mathrm{~kb}$. At present it is impossible to define accurately pressure variations within the field area.

\section{Summary and conclusions}

Textural evidence indicates that the beginning of the first metamorphic event pre-dated $D_{1}$. The presence of pre- $D_{1}$ micas within the rocks strongly suggests that metamorphism to biotite grade was occurring before the onset of deformation. Burial metamorphism may have been initiated by an accumulation of $10-15 \mathrm{~km}$ of rock material in a sedimentary-volcanic pile. Although this material may have been deposited in a number of tectonic settings, the possibility that it accumulated in a failed rift (aulacogen; Burke \& Whiteman 1973) is particularly attractive for the following reasons:

(1) A failed rift provides a deep basin for the deposition of great thicknesses of rock material.

(2) Elevated geothermal gradients, associated with crustal thinning, commonly persist in failed rifts and this would explain the early initiation of metamorphism (Royden et al. 1980).

(3) The central-western Spitsbergen Caledonides form an angle of approximately $110^{\circ}$ with the main Caledonian trend (Birkenmajer 1981).

The peak of $\mathbf{M}_{1}$ metamorphism, which reached garnet grade, is inferred to be synchronous with $D_{1}$. The pressures of metamorphism $(5-7 \mathrm{~kb})$ require between 19 and $27 \mathrm{~km}$ of overburden (assuming a crustal density of $2.65 \mathrm{~g} / \mathrm{cm}^{3}$; Ramberg 1967). This amount of material may have been built up through the continued input of sediment and volcanic material and also through tectonic thickening. At a reference pressure of $6 \pm 1 \mathrm{~kb}$, the various subareas yield geothermal gradient estimates which range from $21 \pm 4$ to $24 \pm 5^{\circ} \mathrm{C} / \mathrm{km}$. These estimates are consistent with, but slightly higher than, those of Morris (1982) $\left(18-21^{\circ} \mathrm{C} / \mathrm{km}\right)$ and Manby $(1983 \mathrm{~b})\left(18-23^{\circ} \mathrm{C} / \mathrm{km}\right)$ for the middle greenschist facies rocks of the Forland Complex. However, the blueschist and eclogites of the Vestgötabreen Formation contain mineral assemblages consistent with geothermal gradients of the order of $15^{\circ} \mathrm{C} / \mathrm{km}$ (Manby 1978b; 
Ohta 1979). Therefore, the lithologies of the Müllerneset Formation and the middle greenschist facies rocks of the Forland Complex were metamorphosed under a different thermal regime from those of the Vestgötabreen Formation. The thermal regimes of metamorphism of the remainder of the Western Complex and the higher grade rocks of the Forland Complex remain to be investigated in detail.

The effects of $\mathbf{M}_{2}$ retrograde metamorphism are local; generally only rocks which have been strongly affected by $\mathrm{D}_{2}$ show pronounced retrogression. The close correlation of retrograde textures and $D_{2}$ deformation strongly suggests that $M_{2}$ occurred synchronous with $D_{2}$. These second metamorphic and deformational events appear to have been triggered by the introduction of fluids, perhaps derived from pressure solution or metamorphic dehydration reactions proceeding at deeper levels of the rock package. The pressures and temperatures of $\mathbf{M}_{2}$ retrogression are poorly constrained but were probably less than those attained during the peak of $M_{1}$ metamorphism.

Acknowledgements. - This work was funded by National Science Foundation Grant \#DPP-8107663 to APM, a Michigan Mineralogical Society Field Research Award to JJA, and Wayne State University, Detroit. We would like to thank W. B. Harland (University of Cambridge) and Norsk Polarinstitutt for their invaluable field support, and D. M. Walniuk, S. J. Birnbaum, and R. F. Ward for many critical and informative discussions. We are also grateful to R. L. Barnett (University of Western Ontario) for his help with the electron microprobe, and to Roslyn Shew Hickey for the typing of many drafts.

\section{References}

Ague, J. J. \& Morris, A. P. 1983: Structure and tectonic development of the Müllerneset Formation, St. Jonsfjorden, Svalbard. Geol. Soc. America Abs. with Programs 15, 512.

Albee, A. L. 1965: Phase equilibria in three assemblages of kyanite-zone pelitic schists, Lincoln Mountain Quadrangle, central Vermont. Jour. Petrology 6, 246-301.

Atkinson, D. J. 1960: Caledonian tectonics of Prins Karls Forland. Int. geol. Cong. 21st Session, Copenhagen 1960. Section $19,17-27$.

Birkenmajer, K. 1981: The geology of Svalbard, the western part of the Barents Sea, and the continental margin of Scandinavia. Pp. 265-329 in Nairn, A. E. M. et al. (eds.): The Ocean Basins and Margins 5.

Brown, E. H. 1969: Some zoned garnets from the greenschist facies. Am. Mineralogist 54, 1662-1677.

Burke, K. \& Whiteman, A. J. 1973: Uplift, rifting and the breakup of Africa. Pp. 735-755 in Tarling, D. H. \& Runcorn, S. K. (eds.): Implications of Continental Drift to the Earth Sciences 12. Rifts and Oceans. Academic Press, London.
Carpenter, R. A. 1974: Pyrrhotite isograd in southeastern Tennessee and southwestern North Carolina. Geol. Soc. America, Bull. 85, 451-456.

Chakraborty, K. R. \& Sen, S. K. 1967: Regional metamorphism of pelitic rocks around Kandra, Singhbkum, Bihar. Contr. Mineralogy Petrology 16, 210-232.

Challinor, A. C. 1967: The structure of Brøggerhalvøya, Spitsbergen. Geol. Mag. 104, 322-336.

Crawford, M. L. 1966: Composition of plagioclase and associated minerals in some schists from Vermont, U.S.A., and South Westland, New Zealand. Contr. Mineralogy Petrology 13, 269-294.

Cutbill, J. L. \& Challinor, A. C. 1965: Revision of the stratigraphical scheme for the Carboniferous and Permian rocks of Spitsbergen and Bjørnøya. Geol. Mag. 102, 418-439.

Dineley, D. L. 1958: A review of the Carboniferous and Permian rocks of the west coast of Vestspitsbergen. Nor. Geol. Tidsskr. 38, 197-219.

Ferry, J. M. \& Spear, F. S. 1978: Experimental calibration of the partitioning of $\mathrm{Fe}$ and $\mathrm{Mg}$ between biotite and garnet. Contr. Mineralogy Petrology 66, 113-117.

Fyfe, W. S., Price, N. J. \& Thompson, A. B. 1978: Fluids in the Earth's Crust. Elsevier, New York. 383 pp.

Ghent, E. D. \& Stout, M. V. 1981: Geobarometry and geothermometry of plagioclase-biotite-garnet-muscovite assemblages. Contr. Mineralogy Petrology 76, 92-97.

Goldman, D. S. \& Albee, A. L. 1977: Correlation of $\mathrm{Mg} / \mathrm{Fe}$ partitioning between garnet and biotite with $\mathrm{O}^{18} / \mathrm{O}^{16}$ partitioning between quartz and magnetite. Am. Jour. Sci. 277, 750-761.

Gregg, W. J. 1978: The production of tabular grain shapes in metamorphic rocks. Tectonophysics 49, T19-T24.

Harland, W. B. \& Wright, N. J. R. 1979: Alternative hypothesis for the pre-Carboniferous evolution of Svalbard. Nor. Polarinst. Skr. 167, 89-117.

Harland, W. B., Horsfield, W. T., Manby, G. M. \& Morris, A. P. 1979: An outline pre-Carboniferous stratigraphy of central-western Spitsbergen. Nor. Polarinst. Skr. 167, 119 144.

Hey, M. H. 1954: A new review of the chlorites. Min. Mag. $30,277-292$.

Hjelle, A., Ohta, Y. \& Winsnes, T. S. 1979: Hecla Hoek rocks of Oscar II Land and Prins Karls Forland, Svalbard. Nor. Polarinst. Skr. 167, 145-169.

Hodges, K. V. \& Spear, F. S. 1982: Geothermometry, geobarometry and the $\mathrm{Al}_{2} \mathrm{SiO}_{5}$ triple point at Mt. Moosilauke, New Hampshire. Am. Mineralogist 67, 1118-1143.

Holtedahl, O. 1911: zur Kenntnis der Karbonablagerungen des Westlichen Spitzbergens. I. Eine Fauna der Moskauer Stufe. Skr. Vidensk. selsk. Christiania. 1. Math. Naturw. Kl. No. $10,1-46$.

Holtedahl, O. 1913: Zur Kenntnis der Karbonablagerungen des Westlichen Spitzbergens. II. Allgemeine stratigraphische und tektonische Beobachtungen. Skr. Vidensk. selsk. Christiania No. 23, 1-91.

Horsfield, W. T. 1969: The geological history of western Oscar II Land, Spitsbergen. Ph.D. thesis, University of Cambridge, $186 \mathrm{pp}$.

Hoschek, G. 1967: Untersuchungen zum stabilitatsbereich von chloritoid und staurolith. Contr. Mineralogy Petrology 14, 123-167.

Krasil'scikov, A. A. \& Kovaleva, G. A. 1979: Precambrian rock-stratigraphic units of the west coast of Spitsbergen. Nor. Polarinst. Skr. 167, 81-88. 
Manby, G. M. 1978a: The geology of north-central Prins Karls Forland. Ph.D. thesis, University of Cambridge, $150 \mathrm{pp}$.

Manby, G. M. 1978b: Aspects of Caledonian metamorphism in central-western Svalbard with particular reference to the glaucophane schists of Oscar II Land. Polarforschung 48, 92-102.

Manby, G. M. 1983a: Primary scapolite from the Forland Complex of Prins Karls Forland, Svalbard. Min. Mag. 47, 89-93.

Manby, G. M. 1983b: A reappraisal of chloritoid-bearing phyllites in the Forland Complex rocks of Prins Karls Forland, Spitsbergen. Min. Mag. 47, 311-318.

Mohr, D. W. \& Newton, R. C. 1983: Kyanite-staurolite metamorphism in sulfidic schists of the Anakeesta Formation, Great Smokey Mountains, North Carolina. Am. Jour. Sci. 283, 97-134.

Morris, A. P. 1979: The geology of south-central Prins Karls Forland, Sualbard. Ph.D. thesis, University of Cambridge, 130 pp.

Morris, A. P. 1982: Low grade (greenschist facies) metamorphism in southern Prins Karls Forland, Svalbard. Polar Research 2, 17-56.

Morris, A. P., Ague, J. J., Kanat, L. H. \& Manby, G. M. 1983; Caledonian orogenesis in central-western Spitsbergen. Geol. Soc. America Abs. with Programs 15, 647.

Ohta, Y. 1979: Blue schists from Motalafjella, western Spitsbergen. Nor. Polarinst. Skr. 167, 171-217.

Orvin, A. K. 1934: Geology of the King's Bay region, Spitsbergen, with special reference to the coal deposits. Skr. Svalb. og Ishavet 57, $195 \mathrm{pp}$.

Perchuk, L. L. 1977: Thermodynamic control of metamorphic processes. Pp. 285-352 in Saxena, S. K. \& Bhattacharji, S. (eds.): Energetics of Geological Processes. Springer-Verlag, New York.

Pigage, L. C. \& Greenwood, H. J. 1982: Internally consistent estimates of pressure and temperature: the staurolite problem. Am. Jour. Sci. 282, 943-969.

Ramberg, H. 1967: Gravity, deformation, and the earth's crust, as studied by centrifugal models. Academic Press, New York, 214 pp.

Royden, L., Sclater, J. G. \& Von Herzen, R. P. 1980: Continental margin subsidence and heat flow: Important par- ameters information of petraleum hydrocarbons. Am. Ass. Pet. Geol., Bull. 64, 173-187.

Schonoveld, C. 1978: Syntectonic growth of garnets: discussion of a new model proposed by M. J. deWit. Geol. Jour. 13, $37-46$.

Scrutton, C. T., Horsfield, W. T. \& Harland, W. B. 1976: A Silurian fauna from west Spitsbergen. Geol. Mag. 113, 519-525.

Spry, A. 1963: Origin and significance of snowball structure in garnet. Jour. Petrology 4, 211-222.

Thompson, A. B. 1976: Mineral reactions in pelitic rocks: II. Calculation of some P-T-X (Fe-Mg) phase relations. Am. Jour. Sci. 276, 401-454.

Thompson, J. B. Jr. 1957: The graphical analysis of mineral assemblages in pelitic schists. Am. Mineralogist 42, 842-858.

Thompson, J. R. Jr \& Norton, S. A. 1968: Paleozoic regional metamorphism in New England and adjacent areas. Pp. 319-327 in Zen, E-an et al. (eds.): Studies of Appalachian Geology. John Wiley, New York.

Tracy, R. J. 1982: Compositional zoning and inclusions in metamorphic minerals. Pp. 355-397 in Ferry, J. M. (ed.): Characterization of Metamorphism Through Mineral Equilibria. Mineral. Soc. America Rev. Mineralogy 10.

Turner, F. J. 1981: Metamorphic Petrology (second edition). McGraw-Hill, New York. 513 pp.

Tyrell, G. W. 1924: The geology of Prince Charles Foreland, Spitsbergen. Trans. Roy. Soc. Edinb. 53, Part 2 Nr. 23, 443-478.

Waddams, P. 1983: The late Precambrian succession in north-west Oscar II land, Spitsbergen. Geol. Mag. 120, 233-252.

Weiss, L. E. 1953: Tectonic features of the Hecla Hoek Formation to the south of St. Jonsfjord, Vestspitsbergen. Geol. Mag. 90, 273-286.

Winkler, H. G. F. 1979: Petrogenesis of Metamorphic Rocks (fifth edition). Springer-Verlag, New York, 348 pp.

Winsnes, T. S. 1965: The Precambrian of Spitsbergen and Bjørnøya. Pp. 1-24 in Rankama, K. (ed.): The Geologic Systems. The Precambrian 2. Interscience Publishers (Wiley), London.

\section{APPENDIX 1 - Mineral analyses}

Sample locations Appendices 1 and 2:

Subarea 1: A006, M3577, M3607

Subarea 2: A035, A080

Subarea 3: A086

GARNET ANALYSES

\begin{tabular}{lccccccccc}
\hline \multicolumn{1}{c}{ Oxide } & $\begin{array}{c}\mathrm{A} 006 \\
(\text { Rim) }\end{array}$ & $\begin{array}{c}\text { A035 } \\
(\text { Rim })\end{array}$ & $\begin{array}{c}\text { A035 } \\
\text { (Core) }\end{array}$ & A086 & $\begin{array}{c}\text { M3577 } \\
\text { (Rim) }\end{array}$ & $\begin{array}{r}\text { M3577 } \\
\text { (Core) }\end{array}$ & $\begin{array}{r}\text { M3607 } \\
\text { (Rim) }\end{array}$ & $\begin{array}{c}\text { M3607 } \\
\text { (Core) }\end{array}$ \\
\hline $\mathrm{SiO}_{2}$ & 37.50 & 36.67 & 37.03 & 36.60 & 37.63 & 37.91 & 37.50 & 38.29 \\
$\mathrm{Al}_{2} \mathrm{O}_{3}$ & 21.22 & 21.57 & 21.72 & 21.52 & 21.23 & 20.89 & 21.32 & 21.32 \\
$\mathrm{FeO}$ & 31.20 & 28.21 & 28.06 & 31.51 & 31.69 & 31.53 & 32.42 & 28.87 \\
$\mathrm{MnO}$ & 4.46 & 9.01 & 9.52 & 6.84 & 3.13 & 3.25 & 2.23 & 4.71 \\
$\mathrm{MgO}$ & 1.33 & 1.50 & 1.48 & 1.15 & 1.36 & 1.17 & 1.36 & 0.96 \\
$\mathrm{CaO}$ & 4.40 & 3.10 & 3.33 & 3.07 & 4.92 & 5.18 & 5.51 & 6.75 \\
\hline \multicolumn{2}{r}{ Total } & 100.11 & 100.06 & 101.14 & 100.69 & 99.96 & 99.93 & 100.34 & 100.90 \\
\hline
\end{tabular}




\begin{tabular}{|c|c|c|c|c|c|c|c|c|}
\hline \multicolumn{9}{|c|}{ Formula (24 oxygens) } \\
\hline $\mathrm{Si}$ & 6.036 & 5.936 & 5.933 & 5.912 & 6.051 & 6.099 & 6.016 & 6.082 \\
\hline $\mathrm{Al}$ & 4.027 & 4.116 & 4.104 & 4.103 & 4.025 & 3.962 & 4.031 & 3.992 \\
\hline $\mathrm{Fe}$ & 4.200 & 3.819 & 3.760 & 4.262 & 4.262 & 4.242 & 4.348 & 3.836 \\
\hline $\mathrm{Mn}$ & 0.608 & 1.235 & 1.292 & 0.937 & 0.426 & 0.443 & 0.305 & 0.663 \\
\hline $\mathrm{Mg}$ & 0.319 & 0.362 & 0.353 & 0.277 & 0.326 & 0.280 & 0.324 & 0.227 \\
\hline $\mathrm{Ca}$ & 0.760 & 0.538 & 0.572 & 0.532 & 0.847 & 0.893 & 0.949 & 1.148 \\
\hline \multicolumn{9}{|c|}{ Mole Fractions } \\
\hline $\mathbf{X}_{\mathrm{Al}}$ & 0.713 & 0.641 & 0.629 & 0.709 & 0.727 & 0.724 & 0.734 & 0.653 \\
\hline $\mathbf{X}_{\mathbf{P y}}$ & 0.054 & 0.061 & 0.059 & 0.046 & 0.056 & 0.049 & 0.055 & 0.039 \\
\hline $\mathbf{X}_{\mathrm{Sp}}$ & 0.103 & 0.207 & 0.216 & 0.156 & 0.073 & 0.076 & 0.051 & 0.113 \\
\hline $\mathbf{X}_{\mathrm{Gr}}$ & 0.129 & 0.090 & 0.096 & 0.089 & 0.145 & 0.152 & 0.160 & 0.195 \\
\hline$\frac{\mathrm{Mg}}{\mathrm{Mg}+\mathrm{Fe}}$ & 0.071 & 0.087 & 0.086 & 0.061 & 0.071 & 0.062 & 0.069 & 0.056 \\
\hline
\end{tabular}

BIOTITE ANALYSES

\begin{tabular}{lrrrrr}
\hline \multicolumn{1}{c}{ Oxide } & $\mathrm{A} 006$ & $\mathrm{~A} 035$ & $\mathrm{~A} 086$ & $\mathrm{M} 3577$ & $\mathrm{M} 3607$ \\
\hline $\mathrm{SiO}_{2}$ & 35.42 & 34.67 & 35.67 & 35.35 & 35.66 \\
$\mathrm{TiO}_{2}$ & 1.38 & 1.42 & 1.45 & 1.41 & 1.48 \\
$\mathrm{Al}_{2} \mathrm{O}_{3}$ & 18.49 & 18.65 & 18.40 & 19.19 & 18.77 \\
$\mathrm{Cr}_{2} \mathrm{O}_{3}$ & - & - & - & - & 0.15 \\
$\mathrm{FeO}$ & 23.46 & 22.01 & 23.83 & 21.67 & 23.20 \\
$\mathrm{MnO}$ & 0.09 & 0.09 & 0.12 & - & 0.07 \\
$\mathrm{MgO}$ & 7.29 & 8.94 & 7.37 & 8.05 & 7.95 \\
$\mathrm{CaO}$ & 0.04 & 0.16 & - & 0.06 & - \\
$\mathrm{Na} 2 \mathrm{O}$ & 0.06 & 0.09 & 0.05 & 0.29 & 0.22 \\
$\mathrm{~K}_{2} \mathrm{O}$ & 8.84 & 8.88 & 8.65 & 8.89 & 9.36 \\
\hline \multicolumn{1}{c}{ Total } & 95.07 & 94.91 & 95.54 & 94.91 & 96.86 \\
\hline
\end{tabular}

\begin{tabular}{lccccc}
\multicolumn{7}{c}{ Formula (22 oxygens) } \\
$\mathrm{Si}$ & 5.488 & 5.363 & 5.501 & 5.441 & 5.432 \\
$\mathrm{Al}$ & 2.512 & 2.637 & 2.499 & 2.559 & 2.568 \\
$\mathrm{\Sigma IV}$ & 8.000 & 8.000 & 8.000 & 8.000 & 8.000 \\
\hline $\mathrm{Al}$ & 0.867 & 0.765 & 0.847 & 0.921 & 0.804 \\
$\mathrm{Ti}$ & 0.160 & 0.164 & 0.168 & 0.164 & 0.169 \\
$\mathrm{Cr}$ & - & - & - & - & 0.018 \\
$\mathrm{Fe}$ & 3.043 & 2.848 & 3.074 & 2.789 & 2.956 \\
$\mathrm{Mn}$ & 0.012 & 0.012 & 0.016 & - & 0.009 \\
$\mathrm{Mg}$ & 1.684 & 2.063 & 1.694 & 1.848 & 1.805 \\
$\Sigma \mathrm{VI}$ & 5.766 & 5.852 & 5.799 & 5.722 & 5.761 \\
\hline $\mathrm{Ca}$ & 0.008 & 0.027 & - & 0.012 & - \\
$\mathrm{Na}$ & 0.020 & 0.027 & 0.015 & 0.090 & 0.064 \\
$\mathrm{~K}$ & 1.750 & 1.754 & 1.702 & 1.746 & 1.820 \\
$\Sigma \mathrm{XII}$ & 1.778 & 1.808 & 1.717 & 1.848 & 1.884 \\
\multicolumn{1}{c}{$\mathrm{Mg}$} & & & & & \\
$\mathrm{Mg}+\mathrm{Fe}$ & 0.356 & 0.420 & 0.355 & 0.399 & 0.379
\end{tabular}

\begin{tabular}{lcccc}
\multicolumn{5}{c}{ Formula (22 oxygens) } \\
$\mathrm{Si}$ & 6.469 & 6.484 & 6.242 & 6.203 \\
$\mathrm{Al}$ & 1.531 & 1.516 & 1.758 & 1.797 \\
$\mathrm{IIV}$ & 8.000 & 8.000 & 8.000 & 8.000 \\
\hline $\mathrm{Al}$ & 3.477 & 3.425 & 3.754 & 3.715 \\
$\mathrm{Ti}$ & 0.027 & 0.031 & 0.023 & 0.029 \\
$\mathrm{Cr}$ & 0.004 & - & - & 0.005 \\
$\mathrm{Fe}$ & 0.258 & 0.262 & 0.168 & 0.211 \\
$\mathrm{Mn}$ & - & - & - & - \\
$\mathrm{Mg}$ & 0.332 & 0.371 & 0.164 & 0.158 \\
$\Sigma \mathrm{VI}$ & 4.098 & 4.089 & 4.109 & 4.118 \\
\hline $\mathrm{Ca}$ & - & 0.004 & - & - \\
$\mathrm{Na}$ & 0.211 & 0.219 & 0.215 & 0.160 \\
$\mathrm{~K}$ & 1.582 & 1.617 & 1.527 & 1.627 \\
$\Sigma \mathrm{XII}$ & 1.793 & 1.840 & 1.742 & 1.787 \\
$\mathrm{Mg}$ & & & & \\
\hline $\mathrm{Mg}+\mathrm{Fe}$ & 0.563 & 0.586 & 0.494 & 0.428
\end{tabular}

MUSCOVITE ANALYSES

\begin{tabular}{lrrrr}
\hline \multicolumn{1}{c}{ Oxide } & A006 & A035 & M3577 & M3607 \\
\hline $\mathrm{SiO}_{2}$ & 49.07 & 49.44 & 47.74 & 46.69 \\
$\mathrm{TiO}_{2}$ & 0.29 & 0.32 & 0.25 & 0.29 \\
$\mathrm{Al}_{2} \mathrm{O}_{3}$ & 32.21 & 31.95 & 35.76 & 35.19 \\
$\mathrm{Cr}_{2} \mathrm{O}_{3}$ & 0.03 & - & - & 0.04 \\
$\mathrm{FeO}$ & 2.35 & 2.38 & 1.54 & 1.90 \\
$\mathrm{MnO}$ & - & - & - & - \\
$\mathrm{MgO}$ & 1.68 & 1.90 & 0.84 & 0.80 \\
$\mathrm{CaO}$ & - & 0.03 & - & - \\
$\mathrm{Na} \mathrm{O}_{2} \mathrm{O}$ & 0.82 & 0.86 & 0.84 & 0.62 \\
$\mathrm{~K}_{2} \mathrm{O}$ & 9.41 & 9.66 & 9.15 & 9.60 \\
\hline \multicolumn{1}{c}{ Total } & 95.86 & 96.54 & 96.12 & 95.13 \\
\hline
\end{tabular}


106 Jay James Ague \& Alan Paul Morris

CHLORITE ANALYSES

\begin{tabular}{|c|c|c|c|c|}
\hline Oxide & A006 & $\mathrm{A} 035^{*}$ & $\mathrm{M}^{3577^{*}}$ & M3607 \\
\hline $\mathrm{SiO}_{2}$ & 25.00 & 26.04 & 24.84 & 24.75 \\
\hline $\mathrm{TiO}_{2}$ & 0.05 & 0.08 & 0.05 & 0.06 \\
\hline $\mathrm{Al}_{2} \mathrm{O}_{3}$ & 21.22 & 20.18 & 22.53 & 20.76 \\
\hline $\mathrm{Cr}_{2} \mathrm{O}_{3}$ & - & 0.03 & - & 0.06 \\
\hline $\mathrm{FeO}$ & 32.05 & 29.23 & 28.71 & 33.38 \\
\hline $\mathrm{MnO}$ & 0.25 & 0.02 & 0.15 & 0.25 \\
\hline $\mathrm{MgO}$ & 10.41 & 12.74 & 12.55 & 9.28 \\
\hline $\mathrm{CaO}$ & 0.04 & 0.02 & 0.06 & - \\
\hline $\mathrm{Na}_{2} \mathrm{O}$ & - & - & 0.03 & 0.02 \\
\hline $\mathrm{K}_{2} \mathrm{O}$ & 0,05 & 0.04 & 0.02 & 0.28 \\
\hline Total & 89.07 & 88.38 & 88.94 & 88.84 \\
\hline
\end{tabular}

\begin{tabular}{ccc} 
& \multicolumn{2}{c}{ Formula (28 oxygens) } \\
$\mathrm{Si}$ & 5.376 & 5.547
\end{tabular}

$\begin{array}{lllll}\text { Si } & 5.376 & 5.547 & 5.248 & 5.392\end{array}$

\begin{tabular}{lllll}
$\mathrm{Al}$ & 2.624 & 2.453 & 2.752 & 2.608 \\
$\mathrm{IIV}$ & 8.000 & 8.000 & 8.000 & 8.000 \\
\hline
\end{tabular}

\begin{tabular}{lcccc}
\hline $\mathrm{Al}$ & 2.757 & 2.617 & 2.859 & 2.723 \\
$\mathrm{Ti}$ & 0.008 & 0.013 & 0.008 & 0.010 \\
$\mathrm{Cr}$ & - & 0.005 & - & 0.010 \\
$\mathrm{Fe}$ & 5.765 & 5.208 & 5.072 & 6.082 \\
$\mathrm{Mn}$ & 0.045 & 0.004 & 0.027 & 0.046 \\
$\mathrm{Mg}$ & 3.337 & 4.046 & 3.952 & 3.012 \\
$\mathrm{Ca}$ & 0.018 & 0.010 & 0.014 & - \\
$\mathrm{Na}$ & - & - & 0.013 & 0.008 \\
$\mathrm{~K}$ & 0.013 & 0.010 & 0.005 & 0.079 \\
$\Sigma$ & 11.943 & 11.913 & 11.950 & 11.970
\end{tabular}

$\begin{array}{lllll}\frac{\mathrm{Mg}}{\mathrm{Mg}+\mathrm{Fe}} & 0.367 & 0.437 & 0.438 & 0.331\end{array}$

- Prograde chlorite
APPENDIX 2 - Whole rock analyses

WHOLE-ROCK ANALYSES

\begin{tabular}{lrrrr}
\hline \multicolumn{1}{c}{ Oxide } & A058* & A080 & A086 & M3607 \\
\hline $\mathrm{SiO}_{2}$ & 62.75 & 45.32 & 61.80 & 61.99 \\
$\mathrm{TiO}_{2}$ & 0.98 & 1.66 & 1.01 & 0.92 \\
$\mathrm{Al}_{2} \mathrm{O}_{3}$ & 17.12 & 26.14 & 17.54 & 17.13 \\
$\mathrm{FeO}^{* *}$ & 6.40 & 8.31 & 7.31 & 7.13 \\
$\mathrm{MnO}$ & 0.06 & 0.08 & 0.06 & 0.08 \\
$\mathrm{MgO}$ & 2.86 & 3.41 & 2.42 & 2.60 \\
$\mathrm{CaO}$ & 1.97 & 0.25 & 0.45 & 1.24 \\
$\mathrm{Na}_{2} \mathrm{O}$ & 2.31 & 1.16 & 2.22 & 2.10 \\
$\mathrm{~K}_{2} \mathrm{O}$ & 3.97 & 7.67 & 3.63 & 3.86 \\
$\mathrm{P}_{2} \mathrm{O}$ & 0.10 & 0.17 & 0.14 & 0.17 \\
$\mathrm{~L} . \mathrm{O} . \mathrm{I} .{ }^{* * *}$ & 1.86 & 5.13 & 2.72 & 2.33 \\
\hline $\mathrm{Total}$ & 100.38 & 99.30 & 99.30 & 99.55 \\
\hline $\mathrm{Mg}$ & & & & \\
\hline $\mathrm{Mg}+\mathrm{Fe}$ & 0.44 & 0.42 & 0.37 & 0.39 \\
\hline
\end{tabular}

* Non-garnetiferous semi-pelite

* All Fe as FeO

*** Loss on ignition
FELDSPAR ANALYSES

\begin{tabular}{|c|c|c|c|c|}
\hline Oxide & $\mathrm{A} 006$ & A035 & A035 & M3577 \\
\hline $\mathrm{SiO}_{2}$ & 63.27 & 67.65 & 63.27 & 63.69 \\
\hline $\mathrm{Al}_{2} \mathrm{O}_{3}$ & 23.54 & 19.75 & 23.10 & 23.22 \\
\hline $\mathrm{CaO}$ & 4.51 & - & 4.03 & 3.88 \\
\hline $\mathrm{Na}_{2} \mathrm{O}$ & 9.16 & 12.45 & 10.03 & 9.60 \\
\hline $\mathrm{K}_{2} \mathrm{O}$ & 0.07 & 0.01 & 0.10 & 0.13 \\
\hline Total & 100.55 & 99.86 & 100.53 & 100.52 \\
\hline \multicolumn{5}{|c|}{ Formula ( 8 oxygens) } \\
\hline $\mathbf{S i}$ & 2.781 & 2.969 & 2.789 & 2.800 \\
\hline Al & 1.219 & 1.023 & 1.199 & 1.203 \\
\hline $\mathrm{Ca}$ & 0.211 & - & 0.191 & 0.183 \\
\hline $\mathrm{Na}$ & 0.781 & 1.059 & 0.855 & 0.818 \\
\hline $\mathbf{K}$ & 0.004 & - & 0.004 & 0.007 \\
\hline \multicolumn{5}{|c|}{ Mole Fractions } \\
\hline $\mathbf{X}_{\mathrm{An}}$ & 0.212 & - & 0.182 & 0.182 \\
\hline $\mathbf{X}_{\mathrm{Ab}}$ & 0.784 & 1.000 & 0.814 & 0.812 \\
\hline $\mathbf{X}_{\mathrm{Or}}$ & 0.004 & - & 0.004 & 0.007 \\
\hline
\end{tabular}

